\title{
The Impact of Traditional Direct Marketing on Creating Brand Awareness: Case Study on IKEA in Jordan
}

\author{
Yousef Ahmad El Dameh ${ }^{1} \&$ Hamad AL Ghadeer ${ }^{1}$ \\ ${ }^{1}$ Marketing, Applied Science University, Jordan \\ Correspondence: Hamad AL Ghadeer, Marketing, Applied Science University, Jordan. E-mail: \\ al-ghadaar@asu.edu.jo \\ Received: January 8, 2019 \\ Accepted: February 6, 2019 \\ Online Published: February 19, 2019 \\ doi:10.5539/ijbm.v14n3p130 \\ URL: https://doi.org/10.5539/ijbm.v14n3p130
}

\begin{abstract}
This study aims to examine the impact of traditional direct marketing represented by flyer, catalog and direct mail on creating brand awareness for the IKEA group in Jordan. Analytical methodologies were used to conduct this quantitative study. The needed data was collected through a questionnaire distributed to (506) respondents from Jordanian customers in the city of Amman. Data was analyzed by SPSS. Descriptive and analytical analysis were conducted using Cronbach's alpha, ANova multiple and simple regression.

The main findings of the study indicate that IKEA group uses the direct marketing tools successfully, disseminates its brand's catalogs and direct mail, these marketing tools achieved brand awareness in the customers' minds, where the flyers occupied the first rank followed by catalogs and direct mail respectively. It is recommended that Jordanian companies turn from mass marketing to direct marketing.
\end{abstract}

Keywords: direct marketing, brand awareness, flyers, direct mail, catalogs, IKEA

\section{Introduction}

Globalization, economic and cultural openness have led to rapid changes and challenges to the economic environment locally and globally (Prarsad et al., 2007). This is due to the high competition between the vast number of current and new competitors in the market.

Brand distinguishes the product from other similar ones which protects both the consumer and the provider from competitors with similar products / services. It is part of our daily life, that each of us requires our needs to be satisfied with different products. Enterprises should understand consumers and anticipate their needs / wants. Marketing managers are in a continuous quest to identify and satisfy consumers' needs and desires. Few researchers discussed the impact of direct marketing in creating brand awareness among consumers (Holetzky, 2008).

Direct marketing has been identified as an interactive marketing system that uses one or more promotion mixes to influence future consumers within a specific geographic area (Walker, 2004).

There are three different labels that refer to direct marketing: direct relationship marketing, direct response marketing and direct order marketing. (Denison \& McDonald 1995).

Branding is a vital issue for any business; it may be considered as a measure of marketing efforts of companies. Branding requires special techniques to create a connection between the company's product and its customers. Once the connection is established, it positively affects the company's revenues and equity. (Aaker, 2012)

This research was conducted to investigate the relationship between direct marketing strategies and creating brand awareness in customers' minds in the case of the IKEA brand in Jordan.

\section{Overview of the Industry and the Population}

IKEA was established in 1943 as a mail company owned by Ingvar Kamprad who was living in a small farming village in the southern area of Sweden under the name Smaland. He was 17 years old when he started transporting the goods of the local county to the nearby train station using a milk van (Edvardsoon and Enquist, 2006).

The IKEA Group of companies (INGKA Holding B.V. and its controlled entities) has an ownership structure that 
ensures independence and a long-term approach.

The INGKA Foundation based in the Netherlands, owns IKEA, therefore, its funds are used in only two ways: either reinvested in the IKEA group or donated for charitable purposes and acts through the INGKA Foundation (Rasmusson \& Sunesson, 2009).

The IKEA Group operates throughout the whole value chain from range strategy and product development to production, distribution and retail. This includes their own manufacturing units, purchasing operation offices, distribution and customer distribution centers, shopping centers and 328 stores in 28 countries. In total, the IKEA Group has operations in 43 countries (Vinay et al., 2017).

"To create a better, everyday life for many people", is the IKEA vision. The IKEA business idea is "to offer a wide range of well-designed, functional home-furnishing products at prices so low that as many people as possible will be able to afford them."

IKEA tries to achieve quality at affordable prices for customers through optimizing their entire value chain, by building long-term supplier relationships, investing in highly automated production and producing large volumes. Also, the bifocal vision of IKEA has enabled the group to be a leader in the furniture market in many countries such as India (Douglas \& Criag, 2011).

The IKEA group has a main financial principle depending on its own resources; long term investments are planned depending on the company's earnings.

The logo in any brand is the key and foundation to their growth. IKEA ensures that their products are accessible to all people by creating a better everyday life in their homes. They reinvest most of their profits in existing IKEA stores and establishing new ones. In addition to product development, they continuously lower their prices. (IKEA, 2016).

\subsection{Problem Statement and Questions}

The business environment has witnessed spectacular changes and developments due to the technological evolution, globalization, cultural and economic openness. These and other factors have led to increasing the intensification of competition (Scott and Stroper, 2003).

The branch of the IKEA group was chosen to discern the impact of traditional direct marketing tools on building brand awareness in the minds of customers in Jordan. The managerial system relies on vertically integrated communication which means that the branches are managed by the head quarters. Hence the problem of this research is summarized in the following phrase: "IKEA uses traditional direct marketing methods (flyers, catalogs and direct mail), to create brand awareness among Jordanian customers, despite the existence of modern methods."

This paper will focus on answering the following questions:

- $\quad$ To what extent does traditional direct marketing influence creating brand awareness?

- Which traditional direct marketing method is the most effective in creating brand awareness for IKEA?

- $\quad$ Are there any differences in respondent answers due their demographics?

\subsection{Research Importance and Objectives}

The significance of this research lies in multi manifestations, the academic, practical, and business enterprises level. The academic level will entail critical research written in English, enriching the content of the Arabic library. This study provides practical evidence of the importance of the role played by traditional tools of direct marketing in creating brand awareness in customer's minds. Evidence of the authenticity of this statement in the business level comes from the IKEA Group which still uses the traditional direct marketing in Jordan successfully.

This research aims to achieve the following objectives:

1- To identify the impact of selected traditional direct marketing tools on creating brand awareness and to identify which of them is the contributor in creating brand awareness for IKEA's customers.

2- To measure the degree of brand awareness (brand, flyers, catalogs, direct mail) of IKEA's commodities among customers in the Jordanian market and to understand any difference in the respondent's answer due to their demographics.

\subsection{Research Limits}

The researcher has faced numerous issues whilst conducting the study. These limits were human (the large 
number of consumers), geographic (the span of the area), cost and time (limited time and resources).

\subsection{Figure 1 Research Model}

Independent Variable

Dependent Variable

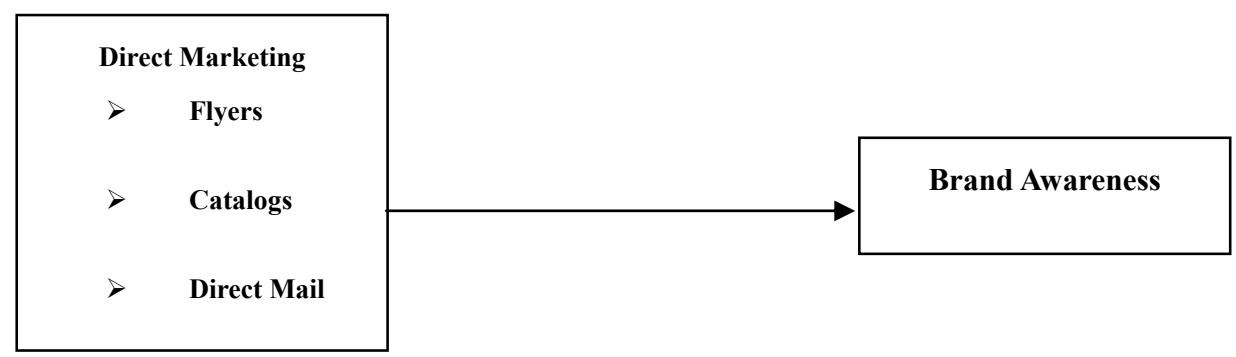

Figure 1. Research model

Adapted, based on previous research (Kotler and Keller, 2012, Osman \& Subhani 2010).

2.5 Research Hypotheses

H0.1: There is no significant impact of direct marketing on creating brand awareness $(\alpha \leq 0.05)$.

This main hypothesis divided to the following minor hypotheses:

H0.1.1: There is no significant impact of flyers on creating brand awareness $(\alpha \leq 0.05)$.

H0.1.2: There is no significant impact of catalog on creating brand awareness $(\alpha \leq 0.05)$.

H0.1.3: There is no significant impact of direct mail on creating brand awareness $(\alpha \leq 0.05)$.

H0.2: There are no differences in consumers' brand awareness due to consumer demographics $(\alpha \leq 0.05)$

\subsection{Operational Definitions}

Direct Marketing: A form of advertising in which physical marketing materials are provided to consumers in order to communicate information about a product or service. (Kliatchko, 2005).

- Flyers: are a form of paper advertisement intended for wide distribution in a public place, handed out to individuals, sent through the mail, distributed by newspaper or door to door (Campo et al., 2003).

- Catalog: is a form of direct marketing where the seller prepares catalogs of merchandise or products and sells directly to the customer. The catalogs are generally in printed form but can also be distributed in CDs (Ching et al., 2003).

- Direct Mail: is a form of marketing in which businesses send letters, postcards or other promotional materials, to current and potential customers or clients. Direct mail campaigns may be targeted to either a consumer or business market.

- Brand Awareness: is the percentage of the population who recognizes the brand (Macdonald and Sharp, 2003). (Trackmaven, 2016)

- Brand Recognition: is used to describe the ability of an organization's target market to identify a brand by its attributes. (Aaker, 2012).

- Brand Recall: is a qualitative measure of how well consumers can connect a brand name with a product type or class of products. (Puppu et al., 2005). Aided recall shows the level to which a brand name is recognized when the actual brand name is promoted. Unaided recall is tested through specific questions in surveys or interviews.

"Top of mind" brand is the first brand to be recalled. (Payne, 2014).

- Attention: is the mental faculty of considering someone or something as interesting or important, or to take notice of (Ay et al., 2010).

\subsection{Theoretical Framework}

Organizations are setting up a marketing strategy to increase sales volume creating brand awareness (Stern, 2006). Increase firm's market share. (Wedel and Kamakura, 2012). Attracting new targeted customers expanding to new markets internationally or locally (Doherty, 2009) maintain relationships with customers and other 
stakeholders (Schniederjans et al, 2012).

Marketing strategy should include the goals and the useful marketing tools and procedures to achieve them. (Swamidass et al., 2001). Product imposes the choosing of marketing type, food products may be better to use mass marketing, while equipment may need direct marketing. (Forsberg, 2004) (Thomas, 2007; Heaton, 2006). Organizations are tending to rely on direct marketing (Casoline \& Thomas, 2002). Social media can be used as tools for direct marketing (Tulen \& Solomon, 2015). Stelzner (2013). The preference of using social media in marketing has been confirmed (Kirtis \& Karahan, 2011). Marketing through social media has an impact on customer equity and intentions or feelings to purchase the product (Kim \& Ko, 2011). The social networks can be a source of information about a certain business for the consumers. They might offer essential data about a business without the need to pay expensive publicity. (Par, 2001). Accordingly, social media tools can be used by business organizations of various sizes and types as a marketing tool (Birkner, 2011). Social media not only to be monopolized by large business organizations, but also for the small and medium enterprises (Kaplan \& Haenlein, 2010). With social media sites, business organizations are able to identify what is being said about their brands and communicate directly with consumers (Reyneke, Pitt, \& Berthon, 2011). Relationships with consumers give SMEs (Small Business Enterprise) the opportunity to use social media as a tool for their marketing strategies (Reyneke et al., 2011). However, (Small Business Trends, 2011) and many SMEs are still unaware of the potentials of social media marketing. Studies conducted by SMB Group (2012) identified that one in five small businesses do not have a strategy in social media.

IKEA, the world's largest home furnishing manufacturer, is one of the early adopters of the digital mode of marketing and has made maximum use of social media clubbed with strong emphasis on its digital catalog which forms the core of the retailer's marketing strategy.

IKEA's digital marketing strategy remains almost uniform - extensive use of social media with separate country pages for respective markets and an ever-increasing stress on digital catalog applications which can be downloaded as applications on smartphones such as Google Play and the Apple Store.

Related literature suggests that there are two basic methods that can be used to advertise and promote products; comprehensive marketing and direct marketing (Bose \& Chen, 2009). Mass marketing usually uses collective media to publish the essential information of the product to current and targeted customers using television, magazines, radio, and newspapers. (Keller, 2009). While direct marketing differs from mass marketing because it's directed to specific denominates of customers (Chiu, 2002), such as individuals or households. Marketers should take into account the customer's background when delivering product information (Harding et al., 2001).

The Direct Marketing Association (DMA) defined direct marketing as communication which uses data in a systematic way to achieve measurable marketing quantitatively through direct contact, or invitation between a company and its current and prospective customers (dma.org.uk). for other definitions as an example see Roddy, (2007), Kotler and Armstrong (2009), Kotler (2012).

Direct marketing has been widely used by marketers in prestigious organizations and has therefore gone beyond reliance on traditional media such as mail and telephone (Roach, 2009). Nowadays the common forms of direct marketing are:

Brochures, Catalogs, Flyers, Newsletters, Post Cards, Coupons, Emails, Targeted Online Display Ads, Phone Calls, Text messages (Merlin et al, 2014).

For the purposes of this research, three forms of direct marketing are chosen; flyers, catalogs, and direct mail.

Flyers can be defined as an offer detailed on a single sheet of paper as an alternative to a brochure or catalog. (Mirande and Kony, 2007) Arnold et al., (2001) reported that retailers in developed countries spend between one third to one half of their marketing budgets on promotion advertised on stored flyers.

Kavassalis et al. (2003) pointed out that McDonald's conducted an unprecedented mobile marketing campaign that was launched through in-store flyers in 2001.

McDonald's has reaped the fruits of this marketing campaign with more than 220,000 responses within 10 weeks, and more than 500,000 subscribers, by the end of the year.

A catalog is a multi-page booklet that contains details about multiple products, including illustrations and more details than a brochure or flyer (Harper Collins Publishers Limited). Dolnicar and Jordann (2007) reported that some customers prefer to receive catalogs through traditional mail for privacy, which is not available when using e-mail. Catalog marketing is very useful for both the retailer and the customer (Earl and Potts, 2004).

Phan and Vogel (2010) suggested that companies that are selling multiple products should identify the number of 
catalogs mailed to individual customers.

Direct mail is a part of unsolicited postal mail in which the seller has the intent of selling products and services to the customer. (Friend et al., 2010).

Conventional direct mail are bearing the companies a high cost, therefore companies should measure and control the effects of such campaigns (Reutterer et al., 2006).

\subsection{Brand Awareness}

For decades, brands have been crucial for building relationships with consumers assuring long-term business success (Tuškej et al., 2013).

Wood (2000). 'Brand is "the likelihood that consumers recognize the existence and availability of a company's product or service. Creating brand awareness is one of the key steps in promoting a product" (Isabel et al., 2013).

A brand that can be recognized by potential customers and associated correctly with a particular product is brand awareness. (Business dictionary, 2016).

Rossiter and Percy wrote in (1992) They described brand awareness as being essential for the communication process to occur, thus it precedes all other steps in the process. No other communication effects can occur without brand awareness occurring.

Rossiter suggested two types of brand awareness: brand recognition and brand recall, depending on the choice situation. The needs fulfilled by the category, or some other type of probe or a cue (Osman \& Subhani, 2010). Obviously, brand recognition occurs in stimulus-based situations, and recall occurs in memory-based situations. Both types of awareness would occur in mixed-choice situations.

Although brand awareness is a major long-term objective of organizations, it is constantly undertaken by managers. Another reason for neglecting measuring brand awareness is that managers of well-established brands may lose interest after conducting several surveys which all report similar high levels of brand awareness. Measurements of awareness allow managers to escape scrutiny and to blame bad sales results on other causal events such as current pricing levels, competitor actions, and sales force efforts (Macdonald \& Sharp, 2003)

Brand recall and brand recognition are two marketing issues that are linked together to access brand awareness. David (2009) emphasized brand awareness through recognition and recall because they involve two tasks; gaining brand name identity and linking it to the product class.

Jin et al., (2008) pointed out that brand names are supportive items to achieve brand awareness. Many organizations also use television video to plant the name of the product in the customer's mind, especially during the presentation of sports (Keller, 2009).

\section{Previous Studies}

Nsour et al. (2016) study aimed to test the effect of marketing by means of social media through two dimensions; company content and user content on the intention to purchase in Jordan. The results showed that there is a strong impact for marketing by social media on the intention to purchase, and there is effect to both company content, and user content in social media means on the intention to purchase.

Risselada et al. (2014) Aimed to analyze the dynamic effects of social influence and direct marketing on the adoption of a new high-technology product. The results showed that social influence has a positive impact on adoption through different social influence variables, and the strength is as important as a weighting factor in models of social influence.

Saleh, et al. (2013) Aimed to measure the relationship between the ad content of Saudi Telecom Company ads on the social media sites and the attitudes of the customers towards the company brand in terms of the gender, age, education level and the nationality of the users. The results showed that there is a positive relationship between the ad content on social media sites and consumer's attitudes towards the brand.

Hulter et al. (2013) in Intention, aimed to analyze how social media activities, in particular, a Facebook page of a car manufacturer, and interactions of the user with these brand related activities affect the perception of brands, and ultimately influence the purchase decision by consumers. The results showed a positive effect of fan page engagement on consumer's brand awareness.

Vries, et al. (2012) aimed to study the "Popularity of Brand Posts on Brand Fan Pages", in particular, the Effects of Social Media Marketing. The results showed that inserting the brand post on the top of the brand fan page enhances the popularity of the brand. Also, the results showed that different factors influence the number of likes, as well as the number of comments, whereas, characteristics of the interactive brand post enhances the number of 
likes.

Kim and Ko (2012) conducted an empirical study to see if Social Media Marketing Activities Enhance Customer Equity. The results showed that SMM activities of luxury fashion brands include five constructs: entertainment, interaction, trendiness, customization and word of mouth, and these marketing activities perceived by customers have a strong impact on all equity drivers.

Naseri and Elliott (2011) examined the Role of Demographics, Social Connectedness and Prior Internet Experience in Adoption of Online Shopping: Applications for Direct marketing. The results showed that demographics alone have a modest role (22.6\%) of the variance in the consumers' actual usage of online shopping, but in the case of adding the other two independent variables to the equation; this rate will reach to $45.4 \%$. This means that demographics have a weak role in customer shopping behavior.

Khashrom, and Ali (2011) aimed to study the behavior of the Syrian consumer in the direction of the brands of sportswear. The results showed that there is a significant impact for the perceived created by the brand in the consumer's mind in the loyalty to the brand, and the perceived quality also has the same effect.

Homburg et al., (2010) aimed to investigate brand awareness in business markets: when is it related to firm performance. The results showed that there is a strong correlation between brand awareness and market performance in markets with similar buying centers, greater buyer time pressure, homogenous products, and a high degree of technological turbulence.

Chi et al (2009) aimed to study the impact of brand awareness on consumer purchase intention. The results showed that there is a significant and positive relationship among the study variables, and the perceived quality and brand loyalty will mediate the effects between brand awareness and purchase intention.

Bose and Chen (2009) aimed to highlight the most important issues that should be included in direct marketing researches to achieve better performance in the direct marketing campaigns. The results showed that performance improvement of marketing campaigns requires marketing researchers to pay more attention to the following issues: data preparation to build a model, conditions in data that lead to use quantitative models, use of alternative data analysis techniques, scalability of quantitative models, use of hybrid data mining models, comparative direct marketing, cross-sell, and up-sell direct marketing.

Keller (2009) study aimed to examine how brands can and should be built and managed in recent marketing communications environment. The study showed that direct marketing tools should be managed to interaction with consumers that rises the degree of brand awareness.

Jin et al., (2008) aimed to investigate the potential inhibitory effects that may occur before through differentiating them from other non-publicized brands. This study was designed for a long period of time that separates between two activities; publicity and advertising, and long-term memory test. The findings showed a positive effect of publicity on brand recall, and publicity effects are much stronger in recall than in recognition.

Barutcu (2007) investigated Attitudes Towards Mobile Marketing Tools: A Study of Turkish Consumers. The results showed that these consumers have positive attitudes towards the following marketing tools; advertising, discount coupons, mobile entertainment, services location, mobile internet and banking.

Andersen (2005) aimed to explore the role of web-enhanced brand communities for supporting social exchanges of professionals. As a case about Coloplast, which is a Danish multinational company that develops, manufactures, and markets medical devices and services related to ostomy, urology, continence, and wound care.

The results showed that web-enhanced brand communities can provide the vital dialog forum between the company and consumers, and this frequent dialog would help the company increase brand awareness among customers.

Trappey and Woodside (2005) aimed to assess the acceptance degree among consumers to the Short message (SMS) as a direct advertising tool and the impact of the message text on watching TV Programs. The results showed that the younger consumers are more likely to accept and respond to S.M.S TV direct marketing.

Madhararam et al., (2005) studied the marketing communication as an element of the company's brand equity strategy. This outcome was accessed through reviewing the related literature as references to their study entitled "Integrated Marketing Communication (IMC) and Brand Identity as Critical Components of Brand Equity Strategy". In addition, marketing communication enables the company to get feedback from customers about the brand.

Nanayana et al., (2004) studied the Temporal Differences in the Role of Marketing Communication in New Product Categories. The main findings showed that the indirect effects would be much smaller for overripe 
brands than for new brands. Also, the direct role dominates in the early stages, while the indirect role dominates in later stages.

Because not all consumers are using the internet, marketers have to rely on other marketing tools such as the postal direct mail marketing methods. In this regard Morimoto and Chang (2006) have studied the "Consumers' Attitudes Toward Unsolicited Commercial Email and Postal Direct Mail Marketing Methods", The results showed a significant difference in how intrusive consumers perceived postal direct mail and unsolicited commercial e-mail (Spam).

Gainer and Padanyi (2002) pointed out that marketing activities can be applied in cultural organizations such as museums, public libraries and others. The result showed that organizations that implemented more market driven activities into their marketing plans were more likely to develop a market-oriented internal culture.

\section{Research Contribution}

This research may involve two essential contributions. Firstly, it will enrich the Arab library by a study conducted by a reputable company in the English Language. Secondly, it is expected that this research will open the eyes of Jordanian companies to turn from relying on traditional marketing tools to modern tools, such as internet capabilities, and social media, which allow the reach of the consumer wherever he is in a lower cost, and enabling him to remember the company's brand for a longer time compared by other marketing tools.

\subsection{Research Approach}

This study used a descriptive and analytical approach to examine the impact of the independent variable, which is direct marketing, used by companies, on the dependent variable, brand awareness formed in the customer's mind.

\subsection{Research Population and Sample}

The research population consists of the Jordanian Consumers which is $(6,613,587)$ Population \& Housing Census, 2016). A convenience sample consists of (506) respondents. Were selected from the government institutions in Amman city. The main reason for the selection of this segment of consumers is that it included only Jordanian citizens.

\subsection{Data Collection Methods}

Both types of data are used in this research that is the primary and secondary data.

Primary data was collected specifically for the purpose of the study by a questionnaire distributed to the selected sample. Secondary data was gathered from previous research, papers, articles and the internet.

\subsection{Questionnaire}

The questionnaire was developed depending on previous literature and interviews with some of the specialist individuals. It was submitted to a number of referents to test for face validity. After that, the researcher tested the questionnaire's validity through the distribution of 15 copies to 15 persons working in the Jordanian government institutions, who answered all questions without any reservations. And because the research is written in English, but the respondents are Arabs, the questionnaire has been translated into Arabic.

The reliability of the questionnaire was achieved through entering the data collected from the respondents into the computer to be analyzed using the SPSS (Statistical Package for Social Sciences) Program. The most important goal of this analysis was to check the reliability of the tool used. In this regard Neuman (2010) has defined reliability as testing the compatibility of the results with the results of similar researches even if they were conducted by another researcher.

While Roberts (2006) has added that validity and reliability are necessary to explain and proof the accuracy of research including the value of the confidence in the results of the research.

\subsection{Reliability}

Table (1) shows the Cronbach' Alpha value which ranges between $(0.79-0.90)$, and total questionnaire items was (0.93), this indicates to acceptable Cronbach' Alpha value for each domain, whenever Cronbach' Alpha value is acceptable if it's more than $(0.60)$ 
Table 1. Cronbach' Alpha value for each domain

\begin{tabular}{ll}
\hline Variables & Cronbach' Alpha value \\
\hline Flyers & 0.90 \\
Catalogs & 0.83 \\
Direct Mail & 0.81 \\
Attention & 0.89 \\
Brand Recognition & 0.81 \\
Recall & 0.79 \\
Total & 0.93 \\
\hline
\end{tabular}

\subsection{Measurement and Analysis}

In order to achieve the objectives of this study, Likert five scale questionnaire was applied from " $1=$ strongly disagree" to " $5=$ strongly agree".

\subsection{Statistical Analysis}

- Descriptive statistics including frequency, percentages, mean and standard deviation were used to explain the consumers response to the research variables.

Analytic statistics including simple regression, multiple regression, ANOVA, $\mathrm{T}$ Test and $\mathrm{F}$ Test were used to analyze the research data and test the hypotheses.

\subsection{Statistical Analysis of Data}

Table 2. Sample characteristics

\begin{tabular}{|c|c|c|c|}
\hline Variable & & Frequency & Percent \% \\
\hline \multirow{3}{*}{ Gender } & Male & 264 & 52.2 \\
\hline & Female & 242 & 47.8 \\
\hline & Total & 506 & 100.0 \\
\hline \multirow{4}{*}{ Marital status } & Single & 214 & 42.3 \\
\hline & Married & 292 & 57.7 \\
\hline & Total & 506 & 100.0 \\
\hline & Less than 35 & 293 & 57.9 \\
\hline \multirow{3}{*}{ Age } & $36-45$ & 123 & 24.3 \\
\hline & $46-55$ & 71 & 14.0 \\
\hline & Above 55 & 19 & 3.8 \\
\hline \multirow{6}{*}{ Monthly Income } & Total & 506 & 100.0 \\
\hline & Less than $500 \mathrm{JD}$ & 221 & 43.7 \\
\hline & $501-1000 \mathrm{JD}$ & 216 & 42.7 \\
\hline & $1001-1500 \mathrm{JD}$ & 42 & 8.3 \\
\hline & More than $1500 \mathrm{JD}$ & 27 & 5.3 \\
\hline & Total & 506 & 100.0 \\
\hline \multirow{5}{*}{ Educational Level } & Secondary school & 95 & 18.8 \\
\hline & Diploma degree & 62 & 12.3 \\
\hline & Bachelor degree & 292 & 57.7 \\
\hline & Post Graduate Studies (Master / PhD) & 57 & 11.3 \\
\hline & Total & 506 & 100.0 \\
\hline
\end{tabular}

Table 2 above indicates:

- Male was the highest category (52.2\%)

- Married consumers was the highest category (57.7\%)

- Less than 35 years old was the highest (57.9\%) age. 
- The highest category in income was less than 1000 JD (86.4\%).

- The highest category in education was Bachelor degree (57.7\%).

Table 3. Level of importance

\begin{tabular}{ll}
\hline Scale & Level of importance \\
\hline Less than $\mathbf{2 . 3 3}$ & Low \\
$2.34-3.66$ & Moderate \\
3.67 or more & High \\
\hline
\end{tabular}

\subsection{Mean and Standard Deviation for Each Factor and Each Item}

Flyers

Table 4. Means and standard deviations for each item by flyers level

\begin{tabular}{llllll}
\hline No. & Statement & Mean & SD & Order & Importance \\
\hline 1 & IKEA constantly issue flyers & 3.45 & 1.14 & 3 & Moderate \\
2 & IKEA flyers contain information about the company and its products & 3.61 & .98 & 1 & Moderate \\
3 & IKEA flyers reach all cities and villages of the Kingdom & 2.74 & 1.18 & 6 & Moderate \\
4 & IKEA flyers include promotional offers & 3.40 & 1.07 & 4 & Moderate \\
5 & IKEA flyers are novel & 3.49 & 1.00 & 2 & Moderate \\
6 & IKEA flyers are many with multiple designs & 3.40 & 1.14 & 5 & Moderate \\
Total & & 3.31 & .92 & --- & Moderate \\
\hline
\end{tabular}

Table 4 shows that the means for flyers ranged between $(2.74-3.61)$ compared with the total instrument mean for the domain (3.31). "IKEA flyers contain information about the company and its products" ranked first "IKEA flyers reach all cities and villages of the Kingdom" ranked on the sixth.

Catalogs

Table 5. Means and standard deviations for each item by catalogs level

\begin{tabular}{llllll}
\hline No. & Statement & Mean & SD & Order & Importance \\
\hline 1 & IKEA constantly issue catalogs for their products & 3.85 & 1.16 & 1 & High \\
2 & IKEA catalogs are in all stores & 2.73 & .95 & 5 & Moderate \\
3 & IKEA catalogs contain sufficient and modern information of its products. & 3.66 & 1.06 & 3 & Moderate \\
4 & You can get the IKEA catalog easily & 3.21 & 1.23 & 4 & Moderate \\
5 & IKEA catalog includes promotions for its products & 3.70 & .91 & 2 & High \\
6 & IKEA catalogs are in all pending hotels and shops halls & 2.76 & 1.00 & 6 & Moderate \\
7 & IKEA catalogs include famous personalities and celebrities & 2.66 & 1.04 & 8 & Moderate \\
8 & IKEA catalogs can be seen in the lobbies of self-employed persons & 2.69 & 1.02 & 7 & Moderate \\
Total & & 3.16 & .71 & --- & Moderate \\
\hline
\end{tabular}

Table 5 shows that the means ranged between $(2.66-3.85)$. "IKEA constantly issue catalogs for their products" ranked first with a mean and standard deviation $(\mathrm{M}=3.85, \mathrm{SD}=1.16)$. "IKEA catalogs include famous personalities and celebrities" ranked on the eighth and last reached (M (2.66), s.d 1.041).

Table 6. Means and standard deviations for each item by direct mail level

\begin{tabular}{llllll}
\hline No. & Statement & Mean & SD & Order & Importance \\
\hline 1 & IKEA use direct mail to communicate with consumers & 2.49 & .98 & 5 & Moderate \\
2 & Direct mail reaches at the right time & 2.67 & .79 & 2 & Moderate \\
3 & Direct mail contains sufficient information on the company (IKEA) & 2.83 & 1.58 & 1 & Moderate \\
4 & IKEA Direct mail reaches different parts of the Kingdom & 2.64 & .79 & 3 & Moderate \\
5 & IKEA Direct constantly contains promotions offers & 2.61 & .78 & 4 & Moderate \\
\hline
\end{tabular}




\begin{tabular}{lllll}
\hline Total & 2.65 & .78 & --- & Moderate \\
\hline
\end{tabular}

Table 6 shows that the means ranged between (2.49-2.83) "Direct mail contains sufficient information on the company (IKEA)" ranked first. "IKEA use direct mail to communicate with consumers" ranked fifth.

Table 7. Means and standard deviations for each item by attention level

\begin{tabular}{|c|c|c|c|c|c|}
\hline No. & Statement & Mean & SD & Order & Importance \\
\hline 1 & IKEA products draw my attention wherever they are & 2.44 & .83 & 4 & Moderate \\
\hline 2 & IKEA products attract me & 2.60 & .77 & 1 & Moderate \\
\hline 4 & IKEA's logo colors interest me & 2.36 & .81 & 5 & Moderate \\
\hline 5 & IKEA is one of the basic milestones on the road to Queen Alia International Airport. & 2.51 & .82 & 3 & Moderate \\
\hline
\end{tabular}

Table 7 shows that the means ranged between $(2.36-2.60)$. "IKEA products attract me" ranked first. "IKEA's logo colors interest me" ranked fifth.

Table 8. Means and standard deviations for each item by recognition level

\begin{tabular}{llllll}
\hline No. & Statement & Mean & SD & Order & Importance \\
\hline 1 & I can easily distinguish IKEA products from others & 2.49 & .83 & 6 & Moderate \\
2 & I can quickly distinguish IKEA products from others & 3.55 & 1.12 & 4 & Moderate \\
3 & I know that I can distinguish IKEA products positively & 3.55 & 1.03 & 3 & Moderate \\
4 & IKEA products differ from any competing products & 3.44 & .97 & 5 & Moderate \\
5 & IKEA brand means a certain level of quality & 3.55 & .99 & 2 & Moderate \\
6 & I know IKEA brand is a high degree of confidence & 4.08 & .94 & 1 & High \\
Total & & 3.44 & .70 & --- & Moderate \\
\hline
\end{tabular}

Table 8 shows that the means ranged between (2.49-4.08). "I know IKEA brand is a high degree of confidence" ranked first. "I can easily distinguish IKEA products from others" ranked sixth.

Table 9. Means and standard deviations for each item by recall level

\begin{tabular}{llllll}
\hline No. & Statement & Mean & SD & Order & Importance \\
\hline 1 & IKEA brand has a special rank in my mind. & 3.53 & 1.05 & 5 & Moderate \\
2 & IKEA brand reminds me of the loved stations in my life & 3.44 & 1.11 & 6 & Moderate \\
3 & IKEA brand is easily characterized and saved & 3.59 & 1.11 & 3 & Moderate \\
4 & I know IKEA products from its brand & 3.71 & 1.13 & 2 & High \\
5 & IKEA brand is Swedish & 3.44 & 1.12 & 7 & Moderate \\
6 & Blue and yellow remind me of the brand of IKEA & 3.58 & .92 & 4 & Moderate \\
7 & The flag of Sweden reminds me of IKEA & 3.78 & 2.34 & 1 & High \\
8 & The IKEA brand is associated with the state of Sweden & 2.87 & 1.03 & 8 & Moderate \\
Total & & 3.49 & .83 & --- & Moderate \\
\hline
\end{tabular}

Table 9 shows that statement "the flag of Sweden reminds me of IKEA" ranked first. "The IKEA brand is associated with the state of Sweden" ranked eighth and last.

\subsection{Test of Hypothesis}

H0.1: There is no statistically significant impact of direct marketing on consumers in creating brand awareness $(\alpha \leq 0.05)$.

To test hypothesis, we can use multiple linear regression analysis, table (10) show that. 
Table 10. Multiple linear regression analysis to examine the impact of direct marketing on consumers in creating brand awareness

\begin{tabular}{lcccccccc}
\hline Variables & $\mathrm{R}$ & $\mathrm{R}^{2}$ & $\mathrm{~F}$ & $\mathrm{~S}$ Sig.F & $\beta_{0}$ & $\beta_{\mathrm{i}}$ & $\mathrm{T}$ & Sig.T \\
\hline Flyers & & & & & & .344 & 8.296 & .000 \\
Catalogs & .709 & .503 & \multirow{2}{*}{167.055} & .000 & 1.367 & -.016 & -.342 & .733 \\
Direct Mail & & & & & & .535 & 14.544 & .000 \\
\hline
\end{tabular}

Table 10 shows the impact of direct marketing on consumers in creating brand awareness. Then the results of the statistical analysis showed a statistically significant impact of direct marketing on consumers in creating brand awareness, with a correlation coefficient $(\mathrm{R}=0.709)$. The coefficient of determination $\mathrm{R}_{2}$ has reached $(0.503 \%)$, which means that the value of $50.3 \%$ of changes in the creating brand awareness from changes in the direct marketing and confirms the calculated $\mathrm{F}$ value (167.055). This indicates the rejection of "There is no statistically significant impact of direct marketing on consumers in creating brand awareness $(\alpha \leq 0.05)$ " and to accept the alternative hypothesis which confirm this impact.

\subsection{Testing Sub-Hypotheses}

H0.1.1: There is no statistically significant impact of flyers on consumers in creating brand awareness $(\alpha \leq 0.05)$. To test hypotheses, we used simple linear regression analysis; table (11) shows that.

Table 11. Simple linear regression analysis to examine the impact of flyers on consumers in creating brand awareness

\begin{tabular}{lllllllll}
\hline Variable & $\mathrm{R}$ & $\mathrm{R} 2$ & $\mathrm{~F}$ & $\mathrm{Sig} . \mathrm{F}$ & $\beta 0$ & $\beta \mathrm{i}$ & $\mathrm{T}$ & Sig.T \\
\hline Flyers & .633 & .401 & 333.226 & .000 & 1.880 & .477 & 18.254 & .000 \\
\hline
\end{tabular}

Table 11 shows the impact of flyers on consumers in creating brand awareness. The results of the statistical analysis showed a statistically significant impact of flyers on consumers in creating brand awareness, with a correlation coefficient $(\mathrm{R}=0.633)$ at the level of significance $(\alpha \leq 0.05)$. The coefficient of determination $\mathrm{R} 2$ has reached $(0.401 \%)$, which means that the value of $40.1 \%$ of changes in the creating brand awareness from changes in the flyers, and confirms this conclusion F value calculated, which amounted to (333.226), which function at the level of significance $(\alpha \leq 0.05)$. This confirms that the regression statistically significant, and a statistically significant impact of flyers on consumers in creating brand awareness, the effect for flyers (0.477), In conclusion, we reject the hypotheses that state "There is no statistically significant impact of flyers on consumers in creating brand awareness $(\alpha \leq 0.05)$." and accept the Ha1.1 which confirms this impact.

H0.1.2: There is no statistically significant impact of catalog on consumers in creating brand awareness $(\alpha \leq$ $0.05)$.

To test hypotheses, we used simple linear regression analysis; table (12) shows that.

Table 12. Simple linear regression analysis to examine the impact of catalog on consumers in creating brand awareness

\begin{tabular}{lllllllll}
\hline Variable & R & R2 & F & Sig.F & $\beta 0$ & $\beta$ i & T & Sig.T \\
\hline Catalog & .499 & .249 & 164.941 & .000 & 2.054 & .327 & 12.843 & .000 \\
\hline
\end{tabular}

Table 12 shows the impact of catalog on consumers in creating brand awareness. The results of the statistical analysis showed the presence of statistically significant impact of catalog on consumers in creating brand awareness, with a correlation coefficient $\mathrm{R}(0.499)$ which is significant at $(\alpha \leq 0.05)$. The coefficient of determination $\mathrm{R}^{2}$ has reached $(0.249 \%$ ), which means that the value of $24.9 \%$ of changes in the creating brand awareness from changes in the catalog, and confirms this conclusion F value calculated, (164.941), which is significant at $(\alpha \leq 0.05)$. This confirms the statistically significant impact of catalog on consumers in creating brand awareness, which means that changes on consumers in creating brand awareness resulting from changes in the catalog value $(0.327)$. This evidence to reject the null hypothesis "There is no statistically significant impact of catalog on consumers in creating brand awareness $(\alpha \leq 0.05)$." and to accept the alternative hypothesis which confirms this impact. 
H0.1.3: There is no statistically significant impact of direct mail on consumers in creating brand awareness $(\alpha \leq$ $0.05)$.

To test hypotheses, we used Simple linear regression analysis; table (13) shows that.

Table 13. simple linear regression analysis to examine the impact of direct mail on consumers in creating brand awareness

\begin{tabular}{lllllllll}
\hline Variable & $\mathrm{R}$ & $\mathrm{R} 2$ & $\mathrm{~F}$ & $\mathrm{Sig} . \mathrm{F}$ & $\beta 0$ & $\beta \mathrm{i}$ & $\mathrm{T}$ & Sig.T \\
\hline Direct Mail & .477 & .228 & 146.980 & .000 & 1.905 & .392 & 12.124 & .000 \\
\hline
\end{tabular}

Table 13 shows the impact of direct mail on consumers in creating brand awareness. The results of the statistical analysis showed the presence of statistically significant impact of direct mail on consumers in creating brand awareness, with a correlation coefficient $\mathrm{R}(0.477)$ which is significant at $(\alpha \leq 0.05)$. The coefficient of determination $\mathrm{R}^{2}$ has reached $(0.228 \%)$. This confirms the conclusion $\mathrm{F}$ value calculated, $(146.980)$, which is significant at $(\alpha \leq 0.05)$. This confirms that the statistically significant impact of direct mail on consumers in creating brand awareness. This indicates to reject the null hypotheses "There is no statistically significant impact of direct mail on consumers in creating brand awareness $(\alpha \leq 0.05)$ " and to accept the alternative which confirms this impact.

H0.2: There is no statistical significant difference in respondent answer due to their demographic characteristics.

To test hypothesis, we can use independent sample T-test and one-way ANOVA to test impact to the consumer demographic characteristics of the sample members on the relationship between direct marketing and brand awareness.

Table 14. ANOVA and T-test result to the consumer demographic

\begin{tabular}{|c|c|c|c|c|c|c|}
\hline Variable & Classification & $\mathrm{N}$ & Mean & SD & Test & Significant level \\
\hline \multirow{2}{*}{ Gender } & Male & 260 & 3.02 & .624 & \multirow{2}{*}{-4.791} & \multirow{2}{*}{$.000 *$} \\
\hline & Female & 240 & 3.27 & .513 & & \\
\hline \multirow[b]{2}{*}{ Marital status } & Single & 210 & 3.11 & .636 & \multirow{3}{*}{-1.073} & \multirow{3}{*}{.284} \\
\hline & Married & 200 & 216 & 546 & & \\
\hline \multirow{5}{*}{ Age } & & & & & & \\
\hline & Less than 35 & 287 & 3.13 & .611 & \multirow{4}{*}{.824} & \multirow{4}{*}{.481} \\
\hline & $36-45$ & 123 & 3.10 & .557 & & \\
\hline & $46-55$ & 71 & 3.22 & .518 & & \\
\hline & Above 55 & 19 & 3.24 & .616 & & \\
\hline \multirow{4}{*}{$\begin{array}{l}\text { Monthly } \\
\text { income }\end{array}$} & Less than $500 \mathrm{JD}$ & 217 & 3.14 & .646 & \multirow{4}{*}{11.832} & \multirow{4}{*}{$.000^{*}$} \\
\hline & $501-1000 \mathrm{JD}$ & 214 & 3.03 & .485 & & \\
\hline & $1001-1500 \mathrm{JD}$ & 42 & 3.35 & .522 & & \\
\hline & More than $1500 \mathrm{JD}$ & 27 & 3.65 & .570 & & \\
\hline \multirow{4}{*}{$\begin{array}{l}\text { Education } \\
\text { level }\end{array}$} & Secondary school & 95 & 2.97 & .690 & \multirow{4}{*}{4.124} & \multirow{4}{*}{$.007 *$} \\
\hline & Diploma degree & 62 & 3.10 & .786 & & \\
\hline & Bachelor degree & 286 & 3.18 & .487 & & \\
\hline & $\begin{array}{l}\text { Post Graduate Studies (Master / } \\
\text { PhD) }\end{array}$ & 57 & 3.26 & .549 & & \\
\hline
\end{tabular}

*significant at $(\alpha \leq 0.05)$.

Table 14 shows that:

The result shows,

1. There is statistical significant difference for brand awareness by gender.

2. That is no statistical significant difference for brand awareness by marital status.

3. That there is statistical significant difference for brand awareness by age. 
4. That there is statistical significant difference for brand awareness by monthly income

5. That there is statistical significant difference for brand awareness by education level.

Table 15. List of referents

\begin{tabular}{llll}
\hline & Name & Rank & University \\
\hline 1 & Dr. Asa'ad Abu Rumman & Prof & Petra \\
2 & Dr. Ghaith Al Abdullah & Assonate & ASU \\
3 & Dr. Marzouq Al qa'ed & Assonate & Islamic University \\
4 & Dr. Abdullah Al Bataineh & Assonate & ASU \\
5 & Dr. Ra'ed Al Gharbat & Assonate & University of Jordan \\
\hline
\end{tabular}

\section{Findings and Recommendations}

\subsection{Findings}

The main findings of the study indicate that IKEA group uses the traditional direct marketing tools successfully, disseminates its brands catalogs and direct mail. These marketing tools achieved brand awareness in the customers' minds, where the flyers occupied the first rank followed by catalogs and direct mail respectively. Consumers may prefer dealing with a reputable company especially when buying durable goods such as furniture.

The sample of the study consists of (506) respondents, and the sample distribution according to the demographic characteristics, the highest frequencies for male, married, less than 35 years and with income less than $500 \mathrm{JD}$ and holding a Bachelor degree.

Since this study aims to examine how IKEA uses traditional direct marketing tools and the impact of this on creating brand awareness among the customers, the statement No. 2 "IKEA Flyers contain information about the company and its products." This approach is natural in respected companies such as IKEA, and this is consistent with was stated by Ruxandra and Razvan (2009), where they pointed out that 766,000 people received monthly information about the tourism services in Scotland. While the lowest rank was for the statement No. 3 which stipulates on "IKEA flyers reach all cities and villages of the Kingdom". The lowest rank may be due to the focusing on the main cities in the host country by large companies especially the foreign companies because of these locations characterized by population density and higher income (Rozenfel, et al, 2011).

For using catalogs as traditional direct marketing tool by IKEA, that issue catalogs constantly by IKEA occupied the first rank from among eight statements, and this was confirmed by Misra (2014) when he pointed out that IKEA rely heavily on its digital catalogs to enhance its marketing strategy. While the last rank was for the statement No. 7 which stipulates that "IKEA Catalogs include famous personalities and celebrities". The researcher believes that this bias will never be from the reputable companies' behavior.

In this regard, Patrick et al (2003) pointed out that the distinction between customers by the company will affect negatively the customer relationship because it firms an unethical behavior such as offensive advertising and adopting unethical products. The direct mail as a tool for direct marketing also used by IKEA to disseminate comprehensive information about the company and its products, where the respondents assure on this through their answers to the statement No. 4, this result is consistent strongly with the study by Chittenden and Retti (2002), where they pointed out that e-mail marketing is increasingly recognized as an effective internet marketing tool. These independent variables have significant impacts on the consumer's attention towards IKEA products because the respondents believe that they have a high degree of confidence in this brand, through statement No. 2 and No. 4 respectively. This attention and this confidence will result in a causal relationship with brand recognition, the evidence to this fact according to the literature; "Brands with greater awareness are more likely to be the focus of attention". (Hoeffler, 2003).

These findings are consistent to the study by Keller (2009) in terms of using direct marketing to build strong brands, while the study Woodside (2005) added the short message as a direct marketing tool. But the studies by Jin et al (2008) differ from this study because they focused on TV advertising.

\subsection{Recommendations}

According to these results, it is recommended that IKEA turn from mass marketing to direct marketing to create the necessary brand awareness. 
IKEA and other furniture companies in Jordan should focus on flyers as it turns to be most important traditional direct marketing for creating brand awareness.

Focuses on the highest frequencies for male, married, less than 35 years and with an income less than $500 \mathrm{JD}$ and holding Bachelor degree.

\section{Future Research}

1. Conducting the same research in other countries where IKEA is open, to compare the results.

2. Conducting the same research for other sectors in the Jordanian market.

3. Conducting studies on non-traditional direct marketing and compare the results with traditional to choose which is more suitable in Jordan and other markets.

\section{Research Limitations}

The study aims to measure the Jordanian customers' awareness of IKEA brand in Jordan attained by their current direct marketing plan as an independent variable.

The researcher has faced the following limitations:

1. The scarcity of research related to direct marketing in Jordan.

2. The cost constrains which affected the number of questionnaires distributed.

\section{References}

Aaker, D. (2012). Building Strong Brands. Free Press.

American Marketing Association.

http//www.ama.org/aboutAMA/Pages/DefinitionofMarketing.aspx

Retrieved from

Andersen, P. H. (2005). Relationship Marketing and Brand Involvement of Professionals through web-enhanced Communities: The Case of Coloplast. Journal of Industrial Marketing management, 34, 285-297. https://doi.org/10.1016/j.indmarman.2004.07.002

Arnold, S. J., Kozinets, R. V., \& Handelman, J. (2001). Hometown Ideology and Retailer Legitimation: The Institutional Semiotics of wal-Mart Flyers. Journal of Retailing, 77, 243-271. https://doi.org/10.1016/S0022-4359(01)00046-X

Ay, C., Aytekin, P., \& Nardalis, S. (2010). Guerilla Marketing Communication Tools and Ethical Problems in Guerilla Advertising. American Journal of Economics and Business Administration, 2(3), 280-286. https://doi.org/10.3844/ajebasp.2010.280.286

Barutcu, S. (2007). Attitudes Towards Mobile Marketing Tools: A Study of Turkish Consumers. Journal of Targeting, Measurement and analysis for Marketing, 16(1), 26-38. http://dx.doi.org/10.1057/palgrave.jt.5750061

Barwise, P., \& Farley, J. U. (2005). The State of Interactive Marketing in Seven countries: Interactive Marketing Comes of Age. Journal of Interactive Marketing, 19(3), 67-80. https://doi.org/10.1002/dir.20044

Bose, I., \& Chen, X. (2009). Quantitative Models for Direct Marketing: A Review from Systems Perspective", European Journal of Operational Research, 195, 1-16. http://dx.doi.org/10.1016/j.ejor.2008.04.006

Campo, Katia et al. (2003). The Impact of Store Flyers on Store Traffic and Store Sales: A Geo-Marketing Aproach. Journal of Retailing, 79(1), 1-16.

Casoline, J. A., \& Thomas, A. R. (2002). Global Manifest Destiny. Dearborn, Inc, Chincago II.

Chi, H. K., Yeh, H., \& Yang, Y. (2009). The Impact of Brand Awareness on Consumer Purchase Intention: The Mediating Effect of Perceived Quality and Brand Loyalty. Journal of International Management Studies, 4(1), 135-144.

Ching, Kevin et al. (2003). Direct Marketing, Indirect Profits: A Strategic Analysis of Dual-Channel Supply Chain. Management Science Informs, 49(1), 1-20.

Chittenden, L., \& Rettie, R. (2003). An Evaluation of E-mail Marketing and Factors Affecting Response. Journal of Targeting Measurement and Analysis for Marketing, 11(3), 203-217. http://dx.doi.org/10.1057/palgrave.jt.5740078

Chiu, C. (2002). A Case - based Customers Classification Approach for Direct Marketing Expert Systems with applications. 
Culnan, M. (1995). Consumer Awareness of Name Removal Procedures: Implications for Direct Marketing. Journal of Direct Marketing, 9(2), 10-19. http://dx.doi.org/10.1002/dir.4000090204

David, A. (2009). Managing Brand Equity. Simon and Schuster.

De Vaus, D. A. (2002). Analyzing Social Science Data. Thousand Oaks, California. Sage.

Doherty, A. M. (2009). Market and Partner Selection processes in International Retail Franchising. Journal of Business Research, 62, 528-534. http://dx.doi.org/10.1016/j.jbusres.2008.06.011

Dolnicar, S., \& Jordann, Y. (2007). A Marketing-Oriented Approach to Responsibility managing Information Privacy Concerns in Direct marketing. Journal of Advertising, 36(2), 123-144.

Douglas, S. P., \& Craig, C. S. (2011). Convergence and Divergence: Developing a Semi Global Marketing Strategy", Journal of International Marketing, 19(1), 82-101.

Earl, P., \& Potts, J. (2004). The Market Preferences. Cambridge Journal of Economies, 28(4), 619-633. http://dx.doi.org/10.1093/cje/28.4.619

Forsberg, F. (2004). Ultrasonic Biomedical Technology, Marketing Versus Clinical Reality. Ultrasonics, 42(1), 17-27. http://dx.doi.org/10.1016/j.ultras.2003.12.027

Friend, L., Costley, C., \& Brown, C. (2010). Spirals of Distrust VS Spirals of Trust in Retail Customer Service: Consumers as Victims or allies. Journal of Service Marketing, 24(6), 458-467. http://dx.doi.org/10.1108/08876041011072573

Gainer, B., \& Padanyi, P. (2002). Applying the Marketing Concept to Cultural Organizations: And Empirical Study of the Relationship Between Market Orientation and Performance. International Journal of Nonprofit and Voluntary Sector Marketing, 7(2), 182-193.

Harding, J. A., Popplewell, K., Fung, R. Y. K., \& Omar, A. R. (2001). A Intelligent Information Framework Relating Customer Requirements and Product Characteristics. Computers in Industry, 44(1), 51-65. http://dx.doi.org/10.1016/S0166-3615(00)00074-9

Hays, N. (2000). Doing psychological research- gathering and analyzing data. Buckingham, Philadelphia, Open University Press.

Heaton, T. (2006). TV News in a Past Modern World: New Metrics and Principles. Retrieved from http://www.thepomoblog.com/papers/pomo54-htm

Hoeffler, S. (2003). The Marketing Advantage of Strong Brands. Brand management, 10(6), 421-445. http://dx.doi.org/10.1057/palgrave.bm.2540139

Holetzky, S. (2008). What is customer loyalty?

Homburg, C., Klarmann, M., \& Schmitt, J. (2010). Brand Awareness in Business Markets: When is it Related to Firm Performance? International Journal of Research in Marketing, 27, 201-212. http://dx.doi.org/10.1016/j.ijresmar.2010.03.004

Hulter, K., Hautz, J., Dennhardt, S., \& Fuller, J. (2013). The Impact of User Interaction in Social Media on Brand Awareness and Purchase Intention: The Case of Mini on Facebook. Journal of Product and Brand Management, 22(5/6), 342-351.

Jin, H., Suh, J., \& Donavan, T. (2008). Salient Effects of publicity in Advertised Brand Recall and Recognition. Journal of Advertizing, 37(1), 45-57.

Johnson, P. A., \& Frankel, B. A. (2005). Direct Marketing Today: Economic Impact", Direct Marketing Association, NY, USA. $\quad$ Retrieved from http://www.the-dma.org/research/economicimpact2005EXecSummary.pdf

Kavassalis, P., Spyropoulou, N., \& Drossos, D. (2003). Mobile Permission Marketing: Framing the Market Inquiry. International Journal of Electronic Commerce, 8(1), 55-79. http://dx.doi.org/10.1080/10864415.2003.11044286

Keller, K. L. (2009). Building Strong Brands in a Modern Marketing Communications Environment. Journal of Marketing Communications, 15(2-3), 139-155. http://dx.doi.org/10.1080/13527260902757530

Khashrom, M., \& Ali, S. (2011). The Impact of Perceived Difference and Perceived Quality on Consumer Loyalty to the Brand. Damascus University Journal of Economic and Legal Sciences, 27(4). 
Kim, A., \& Ko, E. (2012). Do Social Media Marketing Activities Enhance Customer Equity? An Empirical Study of Luxury Fashion Brand. Journal of Business Research, 65(1), 1480-1486. http://dx.doi.org/10.1016/j.jbusres.2011.10.014

Kliatchko, J. (2005). Towards a new Definition of Integrated Marketing Communications (IMC). International Journal of Advertising, 24(1), 7-34. http://dx.doi.org/10.1080/02650487.2005.11072902

Kotler, P., \& Armstrong, G. (2009). Principles of Marketing (12th ed.). Person Prentice Hall.

Kotler, P., \& Kevin, K. (2012). Marketing Management. Praha Grada Publishing.

Macdonald, E., \& Sharp, B. (2003). Management Perceptions of the Importance of Brand Awareness as an Indication of Advertising Effectiveness. Marketing Bulletin, 14.

Madhavaram, Sreedhar et al. (2005). Integrated Marketing Communication (IMC) and Brand Identity As Critical Components of Brand Equity Strategy. Journal of Advertising, 34(4), 69-80.

Mcdonald, E., \& Sharp, B. (2000). Brand Awareness Effects on Consumer Decision Making For a Common Repeat Purchase Product: A Replication. Journal of Business Research, 48, 5-15. http://dx.doi.org/10.1016/S0148-2963(98)00070-8

Miranda, M., \& Konya, L. (2007). Directing Store Flyers to the Appropriate audience", Journal of Retailing and Consumer Services, 14(3), 175-181. http://dx.doi.org/10.1016/j.jretconser.2006.05.002

Misra, B. (2014). How IKEA uses social media to emerge a marketing success. Retrieved from http://www.ikea.com/ms/en_us/thisisikea/company-information/indexhtml

Morgan, N. (2012). Marketing and Business Performance. Journal of the Academic Marketing Science, 40, 102-119.

Morimoto, M., \& Chang, S. (2006). Consumers' Attitudes Toward Unsolicited Commercial Email and Postal Direct Mail Marketing Methods: Intrusive ness, Perceived Loss of Control, and Irritation. Journal of Interactive Advertising, 701(2006), 1-11.

Narayanan, Sridhar et al. (2004). Temporal Differences in the Role of Marketing Communication in New Product Categories. Journal of Marketing Research, 42(3), 278-290. http://dx.doi.org/10.1509/jmkr.2005.42.3.278

Naseri, M., \& Elliot, G. (2011). Role of Demographics, Social Connectedness and Prior Internet Experience in Adoption of Online Shopping: Applications for Direct Marketing. Journal of Targeting, Measurement and Analysis for Marketing, 19. http://dx.doi.org/10.1057/jt.2011.9

Neuman, W. (2000). Social Research Methods: Qualitative and Quantitative Approaches (7th ed.). London: Allyn and Bacon.

Nsour, H., Manasra, A., \& Ziadat, M. (2016). The Effect of marketing by Means of Social Media on the Intention to Purchase in Jordan. The Jordanian Journal of Business Administration, 12(3).

Pappu, R., Quester, P., \& Cooksy, R. (2005). Consumer - based Brand Equity: Improving the Measurement Empirical Evidence. Journal of Product and Brand Management, 14(3), 143-154. http://dx.doi.org/10.1108/10610420510601012

Patrick, V. K., Kristof, D. W., \& Sarah, S. (2003). The relationship Between Consumers' Unethical Behavior and Customer Loyalty in a Retail Environment. Working Paper-University Gent.

Payne, S. (2014). The Art of Asking Questions: Studies in Public Opinion. Princeton University Press. http://dx.doi.org/10.1515/9781400858064

Percy, L., \& Rossiter, J. (1992). A model of brand awareness and brand attitude advertising strategies. Psychology \& Marketing, 9(4), 263-274. http://dx.doi.org/10.1002/mar.4220090402

Phan, D., \& Vogel, D. (2010). A Model of Customer Relationship Management and Business Intelligence Systems for Catalogue and online Retailers. In Formation and Management, 47, 69-77. http://dx.doi.org/10.1016/j.im.2009.09.001

Prasad, E., Rogoff, K., \& Wei, S. (2007). Financial Globalization Growth and Volatility in Developing Countries. National Bureau of Economic Research. http://dx.doi.org/10.7208/chicago/9780226318004.003.0012

Rasmusson, S., \& Sunesson, B. (2009). Coordinated Inventory Control, A Case study on its performance compared to the current system at IKEA. Master Thesis, Lunds University. 
Reuttereer, T., Mild, A., Natter, M., \& Taudes, A. (2006). A Dynamic Segmentation Approach for Targeting and Customizing Direct Marketing Campaigns. Journal of Interactive Marketing, 20(3-4), 43-57. http://dx.doi.org/10.1002/dir.20066

Risselada, H., Verhoef, P., \& Bijmolt, T. (2014). Dynamic Effects of Social Influence and Direct Marketing on the Adoption of High-Technology Products. Journal of marketing, 78, 52-68. http://dx.doi.org/10.1509/jm.11.0592

Roach, G. (2009). Consumer Perceptions of Mobile Phone Marketing: a direct marketing innovation. Direct Marketing an International, 3(2), 124-138. http://dx.doi.org/10.1108/17505930910964786

Roberts, P. (2006). Reliability and Validity in Research Nursing Standard.

Roddy, M. (2002). Direct marketing: A Step - by - step Guide to Effective Planning and Targeting. Longdong, Kogan page.

Rozenfeld, Hernan et al. (2011). The Area and Population of Cities: New Insights from a Different Perspective on Cities. American Economic Review, 101, 2205-2225. http://dx.doi.org/10.1257/aer.101.5.2205

Ruxandra, I., \& Razvan, A. (2009). Strategic Option for Reviving Tourism and Scotland Existing from the Crisis. Administrate Si Management Public, 15, 139.

Saleh, M., Majid, D., Saleh, K., \& Mardi, A. (2013). The Impact of Ad Content in Social Networking Sites on Consumer Attitudes Toward the Brand, The Case of Saudi Telecom Company.

Schmidt-felzmann, H. (2003). Pragmatic principles- methodological pragmatism in the principle-based approach bioethics. Journal of medicine and philosophy, 28(5-6), 581-596. http://dx.doi.org/10.1076/jmep.28.5.581.18817

Schniederjans, M., \& Chig, G. (2012). An Operations Management (CRM) Software", International Journal of Production Research, 50(14), 3974-39878.

Scott, A. J., \& Stroper, M. (2003). Regions, Globalization, Development, Regional Studies.

Stern, B. (2006). What Does Brand Mean? Historical - Analysis Method and Construct Definition", Journal of Academy of marketing Science, 34(2), 216-223. http://dx.doi.org/10.1177/0092070305284991

Stern, B. (2006). What Does Brand Mean? Historical - Analysis Method and Construct Definition. Journal of Academy of marketing Science, 34(2), 216-223. http://dx.doi.org/10.1177/0092070305284991

Stone, M., \& Woodcock, N. (2014). Interactive, Direct and Digital Marketing: A Future that Defends on Better use of Business Intelligence. Journal of Research in Interactive Marketing, 8(1), 4-17.

Subhani, M. I., \& Osman, A. (2012). A Study on the Association between Brand Awareness and Consumer/Brand Loyalty for the Packaged Milk Industry in Pakistan. South Asian Journal of Management Sciences, 5(1), 11-23.

Swamaidass, Paul et al. (2001). The Role of manufacturing and marketing Managers in Strategy Development: Lessons From Three Companies. International Journal of Operations and Production management, 21(7), 933-948. http://dx.doi.org/10.1108/01443570110393423

Thomas, A. (2007). The End of Mass marketing or, why all Successful marketing is now direct marketing. Direct marketing An International Journal, 1(1), 6-16. http://dx.doi.org/10.1108/17505930710734107

Trappey, R., \& Woodside, A. (2005). Consumer Response to Interactive Advertising Campaigns Coupling Short - Message - Service Direct Marketing and TV Commercials. Journal of Advertising Research.

Tulen, T., \& Solomon, M. (2015). Social Media Marketing (2nd ed).

Tuškej, U., Golob, U., \& Podnar, K. (2013). The role of consumer-brand identification in building brand relationships", Journal of Business Research, 66(1), 53-59.

Uematsus, H., \& Mishra, A. (2011). Use of Direct Marketing Strategies by Farmers and their Impact on Farm Business Income. Agricultural and Resources Economic Review, 40(1), 1-19.

Vinay, Ashmita et al. (2017). IKEA: The Furniture Guru - A Exploratory Study. Proceedings of International Conference on Strategies in volatile and uncertain Environment for Emerging Markets.

Vries, L., Gensler, S., \& Leeflang, P. (2012). Popularity of Brand Posts on Brand fan pages: An Investigation of the Effects of Social Media Marketing. Journal of Interactive Marketing, 26, 83-91. http://dx.doi.org/10.1016/j.intmar.2012.01.003 
Walker, T. (2004). Customer Relationship Management for Luxury Skin Care Brands in The Selective Cosmetics Sector.

Wedel, M., \& Wagner, K. (2012). Market Segmentation; Conceptual and Methodological Foundations. Springer Science and Business media, 8.

Wood, L. (2000). Brands and brand Equity: Definition and Management. Management Decision, 38(9), $662-669$. http://dx.doi.org/10.1108/00251740010379100

Yoo, B., Donthy, N., \& Lee, S. (2000). An Examination of Selected Marketing Mix Elements and Brand Equity. Journal of the Academy of Marketing Science, 28(2), 195-211. http://dx.doi.org/10.1177/0092070300282002

\section{Copyrights}

Copyright for this article is retained by the author(s), with first publication rights granted to the journal.

This is an open-access article distributed under the terms and conditions of the Creative Commons Attribution license (http://creativecommons.org/licenses/by/4.0/). 